\title{
World Cinema, Third Cinema
}

\author{
Ewa Mazierska \\ University of Central Lancashire, UK \\ ehmazierska@uclan.ac.uk
}

\begin{abstract}
This article examines the term 'World Cinema' by comparing it to 'world literature', as understood by two German thinkers of the Romantic period: Johann Wolfgang von Goethe and Karl Marx, who attributed universal appeal to it. It argues that World cinema, like world literature, testifies to the unequal distribution of economic and cultural power. World Cinema refers to cinemas of peripheries, cinematic production of 'developing' or Third World countries or non-Hollywood. Moreover, it does not encompass everything which is produced in the peripheries, but only that part, which lends itself to the gaze of (broadly understood) western scholars. Inevitably, such gaze privileges 'canonical works', which have already received national recognition and which due to their subjects, forms or ideologies, align themselves with the production in the centre. However, there are also films created in the peripheries which transcended national boundaries despite being openly local and even hostile to the idea of competing with other films on the global market, especially films made in Hollywood or modelled on Hollywood, such as Third Cinema, whose analysis concludes the discussion.
\end{abstract}

\section{Keywords}

world cinema - world literature - third cinema - capitalism - Marxism

The setting up of the journal 'World Cinema' demonstrates the domination, if not a hegemonic status of the term 'World Cinema' as a category capturing the global production of films, as well as other types of screen media. However, the term is not unproblematic and can even be seen as misleading. Wikipedia informs us in the first sentence of an extended definition of this term: 'World 
cinema is not the sum-total of all films made around the world'. The next sentence states: "Its use is analogous to the use of the term "world literature". Hence, it makes sense to explore the meanings of 'world literature', in order to better capture what is at stake when we use the term 'World Cinema', as well as 'world music', which is largely concurrent with 'World Cinema'.

It is impossible to establish with certainty who first used the term 'world literature', but it is associated with two German thinkers of the Romantic period: Johann Wolfgang von Goethe and Karl Marx. Goethe stated in a letter to a fellow German poet, Johann Eckermann, in 1827 , 'National literature is now a rather unmeaning term; the epoch of world literature is at hand, and everyone must strive to hasten its approach.'

Goethe did not put any ideological or aesthetic restriction on such literature, although it can be deduced that for any literature to reach world or at least international circulation, it has to be translated. Consequently, such literature needs to adhere to the taste of people in more than one country; it has to have something universal about it. German Romantic literature and art in a wider sense provides a model of world literature understood in this way. Take, for example, Friedrich Schiller's 'Ode to Joy' (1785), best known from the final movement to the 'Ninth Symphony' by Ludwig van Beethoven, which became adopted as the Anthem of Europe by the Council of Europe in 1972 and subsequently by the European Union. It includes the following fragment:

Be embraced, Millions!

This kiss to all the world!

Brothers, above the starry canopy

There must dwell a loving Father.

Are you collapsing, millions?

Do you sense the creator, world?

Seek him above the starry canopy!

Above stars must He dwell.

We can see that 'Ode to Joy' refers to the Christian God, but does not evoke Schiller's homeland or any other European country; it talks about humanity at large. One can conjecture that to afford such a universalist attitude, the artist has to enjoy a certain comfort (perfectly conveyed in the title of Schiller's poem), which allows him to transcend the particularities of his class, race, nation, gender or any other characteristics. Most likely, an inmate of a concentration camp, gulag or somebody living under colonial oppression would find it difficult to express such a sense of brotherhood with the entire humanity. For 
such a person the specificity of her or his situation would be of more importance than what s/he shares with other people.

Marx's approach to world literature was in some ways similar to Goethe's; in The Communist Manifesto from 1848 he announced that literature was on the cusp of losing its national characteristics and becoming 'world literature'. He wrote 'The intellectual creations of individual nations become common property. National one-sidedness and narrow-mindedness become more and more impossible, and from the numerous national and local literatures, there arises a world literature' (2008:39).

The difference between Goethe and Marx lies in the latter openly linking the emergence of world literature with the development of capitalism. In step with capitalism progressing through crushing national boundaries and destroying privileges of the older classes, world literature debunks and overcomes national particularities. Marx does not devote much space to world literature, but his attitude to this phenomenon can be gleaned from his attitude to capitalism, as conveyed in The Communist Manifesto and his other publications: it is a progress in relation to what went on before, but not the 'end of history'. World literature overcomes the narrow-mindedness and parochialism of national literatures, it helps to liberate people from the shackles of religion and other old prejudices, but only to put them in the chains of capitalist hegemony. The supposed universalism, which the adherents of world literature promote, is thus in reality a fake universalism: universalism in the service of the God of Money. Here one can think about the overt support of social equality, professed by the European Union, as conveyed by its anthem, yet discreetly introducing policies which are advantageous for the capitalists rather than workers.

Franco Moretti, discussing subsequent developments in world literature, described it, drawing on Immanuel Wallerstein's theory of world system, as simultaneously one and unequal: with a core, and a periphery (and a semi-periphery) that are bound together in a relationship of growing inequality (2000). One, and unequal: one literature (Weltliteratur, singular, as in Goethe and Marx), or perhaps, better, one world literary system (of inter-related literatures); but a system which is different from what Goethe and Marx had hoped for, because it is profoundly unequal. This is what one and unequal means: the destiny of a culture (usually a culture of the periphery) is intersected and altered by another culture (from the core) that 'completely ignores it' (2000: 56 ).

This state of world literature reflects world economic and political relation: the ambition of the periphery and the semi-periphery to join the centre by adopting its formal characteristics and, to some extent, its thematic concerns. Moretti quotes research on Japanese, Brazilian, Indian, Arab and Eastern European novels, to argue that novels produced in these countries and regions 
were in fact similar to western novels. This might indeed be the case. However, it is also possible that the similarity between 'peripheral' and 'central' novels lie largely in the eyes of the beholders, who are mostly western scholars, diasporic scholars working in the West or local scholars trained in the West, through attending foreign universities or studying western literature and consciously or subconsciously adopting the notion that western literature is a yardstick, according to which the rest of literary production should be measured.

Much of what refers to the debates about world literature, also concerns a discourse of world music and World Cinema. World music is geared towards tourists, who search for music which is exotic, but not too exotic, which from the wealth of sounds of melodies distils what can be easily assimilated by the listeners not familiar with the culture of the given country (Bohlman 2002). Similarly, World Cinema typically refers to cinemas of peripheries, cinematic production of 'developing' or Third World countries or non-Hollywood. Moreover, it does not encompass everything which is produced in the peripheries, but only that part, which lends itself to the gaze of (broadly understood) western scholars. Inevitably, such gaze privileges 'canonical works', which have already received national recognition and which due to their subjects, forms or ideologies, align themselves with the production in the centre.

However, such an approach led to a backlash, on the grounds that it perpetuates western hegemony and is negative - by defining what World Cinema is not, rather than what it is. In this spirit, Lúcia Nagib attempted to redefine World Cinema, stating that:

World cinema is simply the cinema of the world. It has no centre. It is not the other, but it is us. It has no beginning and no end, but is a global process. World cinema, as the world itself, is circulation.

- World cinema is not a discipline, but a method, a way of cutting across film history according to waves of relevant films and movements, thus creating flexible geographies.

- As a positive, inclusive, democratic concept, world cinema allows all sorts of theoretical approaches, provided they are not based on the binary perspective. (2006:31).

Although I salute Nagib for her boldness in writing a scholarly manifesto and her desire to democratise film studies, I doubt her programme is realistic and from a Marxist perspective, which I espouse, it is not even desirable. To begin with, claiming that 'world cinema is simply the cinema of the world' does not solve the issue of hierarchies within global film production and discourses tackling them, most importantly 'Hollywood versus the rest', as well as within peripheral cinema itself. At best or at worst, it will make the editors 
of this journal change its name. To change these hierarchies, one needs much more than the will of film scholars; it requires significant transformation in what in Marxist discourse is described as 'the base', namely the property relations, the technical division of labour etc., both within the economies of film production and consumption, as well as in the wider world. I will argue that as long as capitalism remains the hegemonic system within the global economy, the type of cinema represented by Hollywood (spectacular, presenting the adventures of an individual hero), will dominate in film production and consumption. Second, saying that World Cinema is a method does not preclude it being a discipline, as methods often delineate disciplines. For example, fan studies or production studies, which constitute subfields of film studies, are defined by their methods rather than by geographical regions. Moreover, focusing on 'relevant films and movements' brings a distinct risk of choosing those films and movements which are relevant for 'central' (western) scholars, because those of them who do not speak the language in which a given peripheral film was shot, will have to settle for films which are 'translated' through being subtitled and available, being shown in cinemas, sold on DVD or on an internet platform. By the same token, 'relevant films and movements' are inevitably those which constitute a canon or are on the way to receiving canonical status. This brings me to Nagib's third point - 'World Cinema' conceived this way is not democratic - it reflects on and adds to the hierarchies existing in film studies, which largely mirror those existing in the global economy and politics.

This does not mean, however, that films produced in the peripheries and overlooked by audiences and scholars working in the centre are doomed to invisibility or oblivion, far from it. In fact, research on Eastern European cinema, shows that for local audiences 'local films' without pretensions to become feted across the world, which engage with local histories and the present day, and are often unashamedly nationalistic, attract in their countries audiences which are larger than films which peddle universalism and try to lure global audiences. I will be interested to see whether such films will be analysed by contributors to 'World Cinema'.

There are also examples of films created in the peripheries which transcended national boundaries despite being openly local and even hostile to the idea of competing with other films on the global market, especially films made in Hollywood or modelled on Hollywood. I have in mind especially Third Cinema, which Nagib mentions in her essay, albeit briefly, without delving into the ideology of this movement, maybe because, in important ways, it stands in opposition to her idea of inclusive cinema, based on rejecting a binary perspective. 
This movement started at the end of the 196os thanks to the films and political manifestos and produced by directors working in the Third World, most importantly by Fernando Solanas and Octavio Getino, who jointly wrote a manifesto 'Toward a Third Cinema' (1969). Third Cinema, in their conceptualisation, is an overtly political cinema, whose purpose is liberation of the masses from political and economic oppression, chiefly caused by colonialism. It was based on the rejection of the cinema produced in the 'centre' (First Cinema) on the grounds that it serves the political goals of the ruling classes (transnational monopoly capital) and lulls the audience into passivity through its attractive surface. It was also distrustful of the auteurist cinema (Second Cinema), arguing that it expresses the aspirations of the middle layers, the petit bourgeoisie, being often nihilist, pessimist and mystifactory (Chanan 1997:7).

Unlike the idea of 'World Cinema', proposed by Nagib, the proponents of the original Third Cinema embraced the binary perspective. This resulted from their adopting a Marxist stance, according to which the history of mankind is a history of class struggle. Cinema reflects and perpetuates this struggle, either by standing on the side of the oppressors or the oppressed masses. For Marxists, the call for inclusivity or embracing universal values under capitalism, masks acquiescence to the political and aesthetic reality. Third Cinema directors thus proposed films which denounce the status quo, even at the price of being rejected by the 'system'. They did not care about it because they were not concerned about attracting an international audience - their goal was to reach local people and change the local situation, in countries such as Argentina or Chile. Despite and I will argue, largely because of that, Third Cinema films crossed many national borders and we saw the publication of similar manifestos in different countries, reflecting the fact that local issues were recognised as problems affecting communities in many countries, mostly in the Third World, but also in the First and Second world. One of the hopes of the creators of this movement was that filmmaking would become more democratic thanks to changes in the technology, potentially allowing everybody to make a film and thus break the barrier between professionals and amateurs.

However, by the mid-199os, some critics declared Third Cinema dead (Wayne 2001:2; Koh and Ekotte 2009:2). Even if such statements were exaggerated, we have to agree that by the end of the last century Third Cinema lost much of its confidence and novelty, in part reflecting the internal exhaustion, which befalls all cinematic movements, and in part the political situation, marked by the hegemony of neoliberal capitalism, which in many places presented itself as a progressive movement through championing the 
rights of various minorities and oppressed majorities, such as LGBTQ people, ethnic minorities and women. Another factor was a shift in postcolonial studies, on which Third Cinema drew, which rather than underscoring the economic basis and consequences of colonial oppression, focused on cultural difference, as reflected in the work of such scholars as Homi K. Bhabha and Gayatri Spivak. This change was reflected in the Third Cinema films of this period frequently focusing on the past, taking issue with historical struggles, rather than those taking place 'here and now'. Since then some of the old proponents of Third Cinema died, such as Octavio Getino, and others, such as Teshome Gabriel, proposed new programme for Third Cinema which, in fact, was similar to Nagib's programme for World Cinema, by making films 'more complex, more mixed, more ironic' 'less fixed and more heterogeneous' (Gabriel date lacking).

There were also attacks on historical Third Cinema for its supposedly totalitarian character, namely usurping the place of the only spokesperson of the cinemas produced in the Third World and the identities of its creators. A typical, from this perspective, is the recent article by Ivo Ritzer, in which we read:

Third Cinema claimed to represent the oppressed masses, but in fact, it remained throughout in the hands of an educated elite, ironically almost always trained in Europe. Its aesthetics of didacticism and pretension have come under attack and appeared less and less appealing to a new generation of African filmmakers. Since the model of Third Cinema has led to an ideological one-way street, as well as to an aesthetic exhaustion, the multiplicity of new forms of cinematographic practices diversified what might be regarded as African cinema today (2018:24).

Ritzer, in my view, rather than trying honestly to reconstruct the ideology and aesthetics of Third Cinema, creates its caricature, in order to debunk its achievements. He then charts something like a trajectory from Third Cinema in Africa, understood as militant and left cinema to the pluralistic World Cinema in Africa, both in terms of its aesthetics and ideology; a trajectory which presumably can also also observed on other continents. For him, the shift marks progress, as it moves the attention of ordinary viewers and scholars away from what he claims, were the totalitarian instincts of Third Cinema directors, into the pluralistic and democratic realm of World Cinema, where each voice is different, yet equal. However, those preoccupied with the role of cinema as a tool of emancipation of people from the yoke of capitalism and colonialism, regret this trajectory. This is because this shift equals the 
weakening rather than strengthening of the political function of cinema, not least because 'pluralistic' or 'inclusive' politics, which try to defend the interests of all actors, turn out to be either ineffective or end up protecting the interests of the strongest actors.

\section{References}

Bohlman, P.V. (2002). World Music: A Very Short Introduction. Oxford: Oxford University Press.

Chanan, M. (1997). Special Report: The Changing Geography of Third Cinema, Screen $38: 4$, pp. $372-88$.

Ekotte, F. and Koh A., eds. (2009). Rethinking Third Cinema: The Role of Anti-colonial Media and Aesthetics in Postmodernity. Münster: Lit Verlag.

Gabriel,T. (date unavailable).Third Cinema Updated:Exploration of Nomadic Aesthetics \& Narrative Communities, Teshome Gabrielwebsite, http://teshomegabriel.net/thirdcinema-updated (Accessed 6 July 2019).

Getino, O. and Solanas F. (1969). Toward a Third Cinema, Tricontinental, 13 October, pp. 107-132.

Marx, K. and Engels F. (2008) [1848]. The Communist Manifesto. London: Pluto Press. Moretti, F. (2000). Conjectures on World Literature, New Left Review, 1, pp. 54-68.

Nagib, L. (2006). Towards a Positive Definition of World Cinema. In: Dennison S. and Lim S. H., eds., Remapping World Cinema: Identity, Culture and Politics in Film. London: Wallflower Press, pp. 30-54.

Ritzer, I. (2018) The Relational Politics of Media Culture in the Age of Post-Third Cinema, Africa Today, 1, pp. 22-41.

Wayne, M. (2001). Political Film: The Dialectics of Third Cinema. London: Pluto Press. 